\title{
KOGOJEVI POGLEDI NA SLOVENSKO NARODNO PESEM
}

\author{
Borut L o p a r n ik (Ljubljana)
}

Čeprav so bili ustvarjalni nazori, deloma tudi kompozicijska sredstva Marija Kogoja izrazito ekspresionistična, je $\mathrm{v}$ njegovem miselnem in glasbenem svetu delež folklore nenavadno pomemben. Ukvarjal se je z njo od prvih skladateljskih poskusov v Gorici do 1932. leta, ko mu je bolezen onemogočila nadaljnje delo, ter skušal dognati njene bistvene poteze kot skladatelj, kritik, esejist in zgodovinar. Znanstvena cena teh nazorov je sicer pičla, izredna pa je še vedno umetniška vrednost Kogojeve kompozicijske obdelave in uporabe slovenske ljudske pesmi, ki sodi med najboljše, estetsko in vsebinsko najbolj dognane koncertne oživitve našega folklornega izročila. ${ }^{1}$

Prvi dokaz skladateljevih misli je pismo Premrlu iz Gorice ob neki Kokošarjevi zbirki: ${ }^{2}$ »Kar se tiče harmonizacije narodnih pesmi, mislim, da ni harmonizacija sama sebi cilj, nego da imamo doseči oni izraz, ki ga ima pesem v ljudstvu, nekak duh mase. ... In sedaj si predstavljajmo žarečo Primorsko in morda celo Istro in tehtajmo Kokošarjevo „Primorsko'. Harmonizacija je tako indiferentna, da bi jo Bog pljunil iz svojih ust. Sicer, če bi gledali, je harmonizacija čedna ter korektna; pa ali naj je to vse? Zato sem poskusil sam harmonizacijo, v kolikor je ravno boljša

$1 \mathrm{~V}$ skladateljevi zapuščini so ohranjene le tri zborovske priredbe: »Stoji stoji mi polje« (prvi natis $\mathrm{P}=$ Pevec $\mathrm{I}$, notna priloga str. 44), »Narodna« (»Stoji, stoji tam lipica — prvi natis NZ = Naši zbori XII, str. 49-51) ter suita "Trpeča srca«, ki povezuje pesmi »Mene moje srce boli«, »Srce je žalostno« in »Zagorski zvonovi« (gl. mapo »Trpeča srca«), vrhu tega še dva začeta čistopisa in nekaj skic za klavirske variacije na temo pesmi » $\mathrm{Oj}$ ta vojaški boben« (gl. mapo » $\mathrm{Oj}_{\mathrm{j}}$, ta vojaški boben«) ter osnutki in del klavirskega izvlečka nedokončane opere »Kar hočete《 (gl. mapo »Kar hočete« in Loparnik B., Dramaturška in kompozicijska zasnova Kogojeve opere »Kar hočete«, MZ (Muzikološki zbornik) II, Ljubljana 1966, str. 92-93).

2 Gl. zapuščino Stanka Premrla v gl. odd. NUK, mapa »Kronika - korespondenca«. Pismo je bilo napisano 24. II. 1914, torej zadnje mesece pred Kogojevim odhodom na Dunaj. - Za katero zbirko Ivana Kokošarja gre, ni mogoče ugotoviti, skoraj gotovo pa za »Cerkvene pesme priredjene za istarsku školsku mladež i puk«, Trst, 1867 ali nemara za zbornik »Cerkvene pesni nabrane med slovenskim narodom«, Gorica 1885 (I), 1886 (II), 1888 (III), pri katerem je sodeloval. 
sicer ne vem, da je boljša, tj. da odgovarja bolj značaju ljudstva [,] pa le upam. ( $^{3}$

Značilno za Kogoja je, da je ta instinktivno izoblikovani nazor z dobro zadetim estetskim in muzikalnim bistvom povsem usmerjen $\mathrm{v}$ praktično kompozicijsko delo, in nič manj ni pomembno, da ga nikoli ni spremenil, čeprav se je z njim še temeljito ukvarjal, ga skušal zgodovinsko utemeljiti in mu postaviti )znanstvene ${ }^{2}$ temelje. ${ }^{4}$ Po njegovem je ljudska glasba samo »predstopnja umetne $\left({ }^{5}\right.$ Bistveno zanjo je, da »goji narodne posebnosti, ki so $\mathrm{v}$ izvennarodni umetnini najti le prikrite in $\mathrm{v}$ majhni množini (, ${ }^{6}$ )kultiviranje ljudsko-narodne pesmi [ pa ima ] pomen za zdravo glasbeno kulturo, ker ne nasprotuje tendencam umetnosti sploh, ampak jo zagovarjac. ${ }^{7}$ Kogojevi pogledi na nastanek in razvoj slovenske glasbene folklore so mešanica tujih splošnih razlag ter lastnih domnev in sklepanj, s katerimi hoče pojasniti osnovne poteze in zgodovino tega umetnostnega izraza, ne da bi podvomil $\mathrm{v}$ pravilnost svojih trditev in postavljene razvojne sheme. ${ }^{8}$ Prepričan, da je umetnost le sumetnost veleuma, ki

${ }^{3}$ Premrl harmonizacije ni objavil v CG (Cerkveni glasbenik). Skoraj gotovo jo je vrnil skladatelju, kakor ga je ta prosil, vendar je $v$ Kogojevi zapuščini ni in se je verjetno zgubila.

4 Gl. razpravo "O narodni pesmi«, DS XXXIV, str. 176 ter kritike v SN (Slovenski narod), S (Slovenec), DS (Dom in svet) in LZ (Ljubljanski zvon).

5 »Posvetna zborovska produkcija pri Slovencih«, LZ XLIX, str. 641: »Kakor pri vseh narodih, tako je bilo petje tudi v naši glasbi prva stopnja razvoja. ...zadnjo postojanko $v$ razvoju naše narodne pesmi [predstavlja] tako zvana ,doba vozarjenja‘, ko so ljudje vse prepotovali na vozeh. Mogoče se pri nas ni nikoli toliko pelo kakor takrat. ... Tej dobi je sledila prva faza umetne pesmi.« — $O$ umetnosti, posebno glasbeni «, DS XXXII, str. 111: »Umetnost, ki bi po svoji naravi stala splošnosti bliže, bi bila umetnost ljudskih skupin, ali če jih vzamemo razdeljene po narodnosti, narodna. ... Više pa stoji umetnost, ki se ozira le nase.« — »O narodni pesmi«, l. c.: »Če pomislimo, kakšen obseg in kakšno vsebino more imeti umetna narodna glasba in kako omejen je krog sredstev, ki stojijo ljudskonarodni glasbi na razpolago, se moramo definitivno priklopiti mnenju, da je ljudsko narodna pesem šele prva etapa $v$ razvoju nacionalne glasbene umetnosti. Razumljivo je pa to tudi s stališča, da bi $v$ slučaju, da je narodna pesem res višek, postalo delo umetne glasbe čisto brezmiselno in odveč. ... Umetna glasba je — kjer je razvita — od ljudsko-narodnih napevov bogatejša in pomembnejša.«

6 »O umetnosti, posebno glasbeni«, l. c.

7 » narodni pesmi $\ll, l$. $c$.

8 Zadoščajo mu površni časovni termini, »svojčas«, »tedaj«, »tisti čas«, »tej dobi je sledila«, »izjave poročevalcev iz starejše dobe« itd. Prim. o tem Loparnik B., Marij Kogoj - kritik (diplomska naloga), str. 26-28 in op. 2. - Zelo značilna je npr. ohranjena prva stran rkp. o izvorih slovenske narodne pesmi (gl. mapo »Cerkvena glasba - Posvetna zborovska produkcija« v zapuščini): »Drznem si zanemariti zagotovila, ki nam bi jih mogli dati točni zgodovinski podatki in vpostavljam na podlagi prostega razuma mnenje, da so Slovenci že svojčas imeli napeve, ki so jih peli ob prilikah kakor so: verski obredi, ženitve, slučaji smrti, veselice itd., to pa zato, ker najdemo pri vseh narodih, da so si znamenite dogodke iz domačega in narodno-političnega življenja pripovedovali ali peli, pri čemer so se besedila in napevi ustno širili iz roda $v$ rod... Razen tega je vse narode do prepevanja pripeljalo že delo samo. Zlasti ono, kjer je zraven bilo treba istodobnega ali urejeno menjavanega gibanja (veslanje, mlatenje, dviganje težkih predmetov itd.). Kaj so Slovenci peli (katere napeve in kakšne) in kako (eno- ali več-glasno), o tem nimamo najmanjšega pojma.« 
si sam daje postavo«, da je torej )glavno, kdo piše $\left({ }^{9}\right.$ opazuje zgodovino ljudske pesmi kot nastajanje in najpreprostejše združevanje glasbenih prvin, zakaj, »kar je na umetnini narodnega, ... je ton, ki vnema skupine, in napevna ter ritmična manira ${ }^{10}$

Mnogo bolj natančen in neposreden je Kogojev odnos do same muzike. Razume jo kot izraz narodnega značaja: )Slovenec je lirično razpoložen, poln senzitivnosti, zgane ga vsaka senca, vsak še tako rahel gibljaj, pogovarja se z melodijo in tolaži. Lahko se reče, da v njem prevladujejo lastnosti, ki so po svoji barvi bolj ženske. Otožnost, resignacija, zamišljenost na eni strani, a na drugi prisrčnost, šegavost, veselost. Bojevitosti slovenski narodni napevi ne poznajo. (c ${ }^{11} \mathrm{~V}$ tem okviru določi Kogoj tudi pojem tako imenovanega »narodnega sloga(c, ki »bi bil slog jasne pojmljivosti $\mathrm{s}$ posebnim uvaževanjem karakterističnega značaja narodne psiheঞ, vendar pa se spričo umetniško nezrele ljudske pesmi »nanaša [samo] na gotov del slogovne tehnike, na kar najbolj izrazovito, do plastične ponazorjenosti izdelano podajanje ${ }^{12}{ }^{12}$ - Osnovni potezi folklorne muzike sta melodija in ritem..$^{13}$ Kar zadeva melodijo, se Kogoj odločno upira misli, da so značilnosti slovenskih napevov alpske, čeprav priznava, da pravih ne pozna in samo našteva nekaj pesmi, ki se mu zde tipične. ${ }^{14}$ Zanaša se torej na instinkt, ne da bi ga mikalo prodreti v značilnosti melosa, ki ga

9 »O umetnosti, posebno glasbeni «, DS XXXI, str. 28.

10 Op. cit., DS XXXII, str. 111. Kaj je »ton«, pojasnjuje ibid.: »Različne skupine različnih narodov omogočujejo različno umetniško pojmovanje. Kar jih razlikuje, je posebno priljubljeno izražanje in ton, $v$ katerem se zrcalijo duševne lastnosti in osebno dopadenje nad njim.«

11 »O narodni pesmi «, str. 174. Isto misel srečamo že v članku »O Avgustu Lebanu«, S XLVII, št. 249, 25. XII. 1919, božična priloga: »Iz večine Lebanovih skladb diha otožna nežnost in milina, značaj, ki se mi zdi najbolj značilen za slovensko narodno pesem, kakor tudi za precejšnje število naših komponistov... Razume se, da značaj, ki ga nosijo slovenske glasbene umetnine ni vedno ta, saj je med njimi tudi dovolj živahnih pesmi, četudi se mora reči, da manj poznanih. Res pa je, da sta nam pomp in bojevitost po večini bolj tuja, vsaj kadar sta resno vzeta.« - Enako presoja Kogoj tudi slovenskost sodobnih del. Npr.: Lajovic »je pri odberi značaja $v$ mnogih pesmih prišel do zaključka, ki Slovenca ne zadovolji. Medtem ko ostane slovenska pesem lirična tudi, kadar je vesela, prihaja $v$ Lajovčevi zbirki [sc. v »Dvanajstih zborih"] na površje neka zunanjost, ki je lastna nekaterim srbohrvatskim napevom. ... mislim, da je značaj skladb za različne nacije najbolj značilen.« (»O nekaterih glasbenih izdanjih«, DS XXXV, str. 240).

12 » $O$ umetnosti, posebno glasbeni«, DS XXXII, str. 111.

13 S XLVIII, št. 58, 11. III. 1920. — »Prosveta. Medjimurski večer...«: "Kakor pri narodni pesmi sploh, tako so tudi pri teh ritmični in melodični elementi najvažnejše, kar postane pri takem koncertu le še bolj očito. Dobro predavati narodno pesem se pravi torej na učinkovit način prednašati te elemente, kar se zgodi z niansiranjem dinamike in tempa.«

$14 » O$ narodni pesmi , ibid. - Str. 175: »Kaj je slovenskim napevom skupnega, kaj se poleg značaja $v$ njih zopet ponavlja, je težko ugotoviti, ker je obširnejši material takorekoč nedostopen.« - Str. 176: »Potem so še druge pesmi, ki veljajo za narodne. To so vse one, ki živijo... od opisovanja prve in pete stopnje z neizrazito melodiko. Eden bolj razvitih eksemplarov tega tipa je zadnje čase $\mathbf{v}$ Ljubljani zaslovela koroška pesem ,Tam čez izaro‘. Napev je alpske konstrukcije, vendar je pomešan z elementi, ki niso značilni za alpsko pesem.« 
občuti kot pristno domačega. ${ }^{15}$ Glede dura in mola sodi, da sta bila nekoč verjetno enako razširjena, saj »bi bilo neverjetno, da bi se bili ravno Slovenci tako izolirali na durov in molov način, medtem ko sta preprezala evropski svet oba๕, vrhu tega pa »ostane otožnost za slovensko narodno pesem značilna tudi $\mathrm{v}$ duru, tako da značaj mnogih narodnih pesmi $\mathrm{v}$ duru podaja običajni vtis molovih napevov c ${ }^{16} \mathrm{~V}$ davnini je po njegovem mnenju poznalo ljudstvo le določeno, razmeroma omejeno število melodij, vse poznejše pa so se razvile iz njih kot bolj ali manj samostojne variante. ${ }^{17} \mathrm{Da}$ bi svojo misel potrdil, primerja Kogoj napeve »Oj ta vojaški boben(, )Se davno mrači (c, )Sonce čez hribček gre((, )Sonce mi zadaj gre( in »Ptička veselo nad hiško letic ter opozarja, da so $\mathrm{v}$ njih spremenjeni )tempo, takt, ritem in značaj.$^{18}$ Pri tem ga ne zanimajo historično starejše oblike, temveč izpovedno globlje in izrazitejše: ravna torej kot umetnik, ne kot znanstvenik. ${ }^{19}$ — Manj natančni in razpredeni so Kogojevi nazori o ritmu v slovenski narodni pesmi. Če odštejemo pripombo o

$15 \mathrm{~S}$ XLVIII, št. 36, 14. II. 1920 — $\gg$ Prosveta. Koncert, ki ga je $\mathbf{v}$ nedeljo priredila ...«: »Pesmi, ki so se proizvajale [,] sicer niso bile ravno značilne in torej razlika med našimi in recimo češkimi narodnimi pesmimi ni bila očividna ... Po značilnosti napeva in dobri koncepciji bi od slovenskih narodnih, ki so se pele, moral v prvi vrsti imenovati ,Plavarsko" in "Barčico" iz beneške Slovenije... Ostale... so po koncepciji šibkejše, so nekak kompromis med pristno slovensko narodno in alpsko pesmijo Nemcev.« - S XLVIII, št. 58, 11. III. 1920 - »Prosveta. Medjimurski večer...«: »Pesmi iz Medjimurja imajo na sebi lastnosti, ki so lastne slovenskim in hrvatskim, srbskim in tudi slovaškim narodnim pesmim.« — »O narodni pesmi«, str. 175: »Če kdo hoče napraviti zbirko, se mora sprijazniti z mislijo, da se je treba pečati tudi z vprašanjem, katere pesmi sploh spadajo $v$ tako zbirko. Vedeti moramo, katere pesmi so tako karakteristične, da jih smemo kot narodne predati širši javnosti ...«

$16 \gg O$ narodni pesmi $\ll$, str. 174.

17 To trditev najdemo razloženo na hrbtni strani sporeda za koncert Ševčikovega godalnega kvarteta, ki je nastopil v Ljubljani 2. XII. 1920 (gl. mapo »Cerkvena glasba - Posvetna zborovska produkcija «) »Zgodilo se je, da je bilo več tekstov [.] ki bi jih ljudje radi peli [.] na razpolago [,] premalo pa napevov. Tedaj so si ljudje pomagali tako [,] da so začeli na eni in isti napev peti razna besedila. In tako je prišlo do tega [,] da se je napev moral predrugačiti. Prvič zato, ker sicer nista šla skupaj napev in besedilo in potem zaradi različne vsebine in drugačnega ... [?] ... posameznih pesem.«

18 »O narodni pesmi «, str. 175. »Posebno karakter napevov je čisto različen.«

19 Op.cit., str. 176: "Res, čudno je, kako napačne predstave imajo ljudje o prisotnosti in značilnosti slovenskih pesmi....treba [se je] potruditi, da se izmed variant izsledi najboljša, ker še nikakor ni dovolj, da je nabiratelj pesem dobil med narodom.« — Str. 175: »Če se najdejo variante, moramo vedeti ... katere pesmi so tako karakteristične, da jih smemo kot narodne predati širši javnosti.« - Podobno sodi Kogoj tudi v kritikah. Npr.: »Prepeva se in prepeva, ali kdo pravzaprav je še pokazal pravo lepoto slovenskih narodnih pesmi? Kdo je pokazal $\mathbf{v}$ izbiri in prednašanju njen glavni značaj? Živim $\mathbf{v}$ prepričanju, da je prav malo ljudi, ki bi za ta značaj vedeli, zlasti pa, ki bi poznali pesmi, v katerih se ta značaj izraža.« (»Iz koncertne dvorane«, DS XXXIII, str. 203) —»Težko bi bilo reči, da ima le eden [od venčkov narodnih pesmi] kakšno muzikalno vrednost, bodisi po načinu prireditve, bodisi po izbiri napevov. ... Sicer pa ni imel izmed teh prirediteljev nobeden izrecnega namena, dati narodni pesmi dostojno lice.« (»Posvetna zborovska produkcija pri Slovencih«, LZ XLIX, str. 643) — »[Adamičevih] ,6 narodnih pesmi za ženski zbor ima boljše melodije in boljše tekste kakor jih imajo po navadi pete narodne.« (»Koncerti«, LZ LII, str. 320). 
pogostokrat pomanjkljivem zapisovanju folklornega blaga, ki jo velja razumeti tudi kot kritiko ritmičnih in metričnih nejasnosti dotedanjih izdaj, ${ }^{20}$ so omejeni na misel, da $)$ so slovenski napevi [neredko] prav umetno zloženi in se časih pojejo $\mathrm{v}$ peterodelnih metrih $\left(.^{21} \mathrm{Kar}\right.$ zadeva njihovo obliko, izvemo samo, »da eno- ali dvakratni motiv, ki se zapoje v prvi kitici samo enkrat, raste [v več pesmih] s številom kitic, tako da postane $\mathrm{v}$ zadnjih kiticah obširnejši nego vsi ostali elementi. Mala fraza se tako polagoma razširi, da postane vsaka kitica za gotov obseg daljša in $\mathrm{v}$ njem končno ona sama prevlada(, $\mathrm{v}$ variantah pa »so napevi [tudi formalno] spremenjeni na prav zanimiv način (. ${ }^{22}$ Očitno se zdi Kogoju oblika slovenskih narodnih pesmi dovolj preprosta in pregledna, omejena na najbolj preproste kompozicijske elemente in ji zato (kakor ritmu) ne posveča posebne pozornosti.

Skoraj toliko misli kot melodičnim značilnostim pa je $\mathrm{v}$ njegovih zapisih odmerjeno harmonskemu ustroju slovenske folklore, seveda s stališča skladatelja - ekspresionista, ki mu je harmonska podoba izbrane melodije osrednje območje njene globlje vsebinske interpretacije. Prepričan, da alpske poteze niso bistvene za pristno slovenski melos, se najbolj odločno upira »omejitvi harmonije na prvo in peto stopnjo,${ }^{23} \mathrm{kar}$ je brez dvoma tudi posledica folklornega prostora, $\mathrm{v}$ katerem je doraščal. ${ }^{24}$ Tako ga v nazorih o prirejanju ljudskih pesmi folklorne značilnosti, kakor jih pozna, ne omejujejo, ampak spodbujajo. »O harmonizaciji narodnih napevor se misli, da je dovolj, če je le kolikor mogoče primitivna. Ali v resnici je naloga harmonizatorja, podati umetniški vtis napeva, to je: dati s harmonizacijo napevu priliko, da se pokažejo na površju vse one točke, ki so zanj značilne.(( ${ }^{25} \mathrm{Tu}$ je za Kogoja jedro problema: )Splošno se govori, da ni v slovenskih napevih ,nič samosvojega'. Trdim, da to izvira samo iz dejstva, da nimamo dobrih prireditev in da so srbske narodne

20 »O narodni pesmi $\ll$, str. 176.

21 Op. cit., str. 175. Prvič srečamo to misel že $\mathbf{v}$ razpravi » $O$ umetnosti, posebno glasbeni«, DS XXXII, str. 112: »Če že vzamemo takt za podlago skladateljevanja, zakaj potem le nekatere in ne vseh? $\mathrm{V}$ peterodobnem in posebno $\mathrm{v}$ sedmerodobnem so se poskušali izjemoma le malokateri in s takim trudom in $s$ tako silo, medtem ko se ju v naravni preprostosti poslužuje že narodna pesem.« Pozneje se je Kogoj dotaknil tega vprašanja samo še v kritiki »Dvanajstih zborov« Antona Lajovca (»O nekaterih glasbenih izdanjih«, l. c.): »Več [slovenskih] značilnosti je $v$ zunanjostih, kakor so neenake taktove vrste $(5 / 4,7 / 4)$, ki jih skladatelj uporablja in so za naše pesmi kolikortoliko značilne.《

$22 \gg O$ narodni pesmi«, l. c. - Tudi v kritikah se Kogoj ustavi ob obliki narodnih pesmi samo enkrat (S XLVIII, št. 58, 11. III. 1920 - »Prosveta. Medjimurski večer...«): Medjimurske pesmi »obstojijo iz komaj enega stavka [.] do izrazite dvodelne oblike pridejo le tu pa tam«.

$23 \gg$ O narodni pesmi $\ll$, str. 174.

${ }^{24}$ Kogoj $\mathbf{v}$ svojih spisih sicer ne omenja harmonskih zvez, ki jih pozna ljudsko petje, da pa je o njih razmišljal, dokazuje navedba v $\gg$ Studiji o stilu slovenske ljudske glasbe "Stanka Vurnika (DS XLIII, str. 316-317): "Značilno za te pesmi [sc. za slovenske sredozemske pesmi], kakor me je na to opozoril skladatelj M. Kogoj, je, da rabijo Slovenci $v$ tem kulturnem pasu neke prehodne akorde, disonance, kakor kvartsekstakord, septakord, nonski akord za samostojne harmonične dražljaje in ne samo za harmoničen medčlen.«

25 »O narodni pesmi $\ll$, str. 176. Prim. s cit. pismom Stanku Premrlu. 
danes tako znamenite le radi tega, ker so doživele dobre prireditve. $\left(^{26}\right.$ Pojmov »harmonizacija ( in »priredbac Kogoj sicer ne loči natanko, kakor pri pisanju sploh ni posebno pozoren na dosledno oblikovanje misli, ${ }^{27}$ skrajno natančno, z občudovanja vrednim umetniškim posluhom in estetskim instinktom pa presoja sleherno izvedeno ali objavljeno narodno pesem. ${ }^{28}$ Odklanja $)$ prireditve za zbor, v katere so uvedeni solisti, [ker] so od prve do zadnje ponesrečene [in] ker $\mathrm{v}$ nikakem oziru ne odgovarjajo zahtevam, ki jih ima prireditelj do napevov. (c9 ${ }^{29}$ Prav tako zgrešeni se mu zdijo venčki narodnih pesmi, )ker si [v njih] slede brezmiselno različni napevi brez vsake notranje motivacije.$^{30} \mathrm{Da}$ bi se razmere izboljšale in bi občinstvo, predvsem pa glasbeniki, spoznali pravo bogastvo slovenske folklore, črpali iz njega motive za obdelavo in znanje o pristnem ljudskem melosu, terja Kogoj »vzorno izdajo ( narodnih pesmi ${ }^{31}$

26 Ibid. Seveda pa je Kogoj oster nasprotnik posnemanja: »Bajukova prireditev ,Dievojka je ružu brala" skuša preveč biti taka, kakor nekatere iz srbskih ciklov Mokranjca.« (S XLVIII, št. 36, 14. II. 1920 — »Prosveta. Koncert, ki ga je v nedeljo priredila...«) Upira se tudi favoriziranemu načelu, naj bi slovenski izvajalci in skladatelji segali po delih s folklorno tematiko drugih jugoslovanskih narodov ali uporabljali njihove napeve v lastnih skladbah: "Lajovičeva pesem „Japan opeva kras domače zemlje, ki leži v novi državi na jugu, ko se naslanja v svojem občutju na narodno pesem.« (SN LII, št. 82, 7. IV. 1919 - »Koncert ,Ljubljanskega Zvona" «).

27 Gl. o tem Loparnik B., Marij Kogoj - kritik, str. 3-4. Priredba pesmi "Stoji, stoji mi polje« je ob prvi objavi v P I, notna priloga, str. 44 označena $\mathrm{s}$ »harm[oniziral]«, sam pa jo v »Koncertnem pregledu«, LZ LII, str. 191 imenuje $»$ priredba«.

${ }_{28}$ Npr.: "Srbska ,Pod Pendžeri" je od Konjovića okusno prirejena in sama na sebi dovolj zanimiva." (»Koncert, Ljubljanslega Zvona" "SN, l. c.) - »Alabijeva prireditev ruske narodne "Slavček' je neznatna.« (»Kobler - Lovše«, SN LII, št. 94, 22. IV. 1919) — $\gg$ Po značilnosti napeva in dobri koncepciji bi od slovenskih narodnih ... moral v prvi vrsti imenovati "Plavarsko" in "Barčico" iz beneške Slovenije, s katerih okusno prireditvijo O. Deva se moramo vsekakor strinjati.« (»Koncert, ki ga je v nedeljo priredila ...«, S XLVIII, št. 36, 14. II. 1920, »Prosveta «) - Kot višek neprimernega ravnanja $z$ narodnimi napevi navajamo Parmove "Slovenske cvetke" kjer najdeš napev pesmi , $\mathrm{Oj}$ ta vojaški boben" $\mathrm{v}$ tako škandalozni prireditvi, da se človek zdrzne nad to brutalnostjo.« (»O narodni pesmi $\ll$, str. 176).

29 »O narodni pesmi $\ll$, l. c.

30 Ibid. Isto misel najdemo že v kritiki »Kobler - Lovše«, SN LII, št. 94, 22. IV. 1919: »Za proizvajano ciklično prireditev narodnih [se ni] preveč zavzemati. Ne zavračam s tem ciklične prireditve sploh, kakršne so v rabi [,] jih pa po večini vendar pri sebi odklanjam."

31 »O narodni pesmi«, 1. c.: »Kar se tiče o izberi obdelovalnega gradiva, se mora z žalostjo konstatirati, da vzorne izdaje nimamo. Ves material, ki je nakopičen v Štrekljevih ,Slovenskih narodnih pesmih', leži še neuporabljen.« - Kogoj je notne zapise Štrekljeve zbirke poznal (gl. »O narodni pesmi«, str. 174 in op. $35,36 \mathrm{v}$ tej razpravi) in ob delu za opero "Kar hočete« pregledoval tudi "Južnoslovjenske narodne popievke« Franja Kuhača (gl. Loparnik B., Dramaturška in kompozicijska zasnova Kogojeve opere »Kar hočete«, MZ II, str. 92). Sčasoma se mu je misel o »vzorni izdaji« razširila v idejo »sistematične zbirke vseh narodnih pesmi« (SN LXI, št. 137, 16. VI. 1928 - „Kaj ustvarjajo in snujejo naši umetniki. Nadaljevanje zanimive ankete o delovanju pionirjev slovenske kulture. Marij Kogoj.«) O njegovem zanimanju priča tudi v zapuščini ohranjeni list (gl. mapo »Cerkvena glasba - Posvetna zborovska produkcija«), na katerega si je deloma $\mathrm{z}$ roko deloma s strojem izpisal naslove pesmi, objavljenih $\mathrm{v}$ »Zbirkah slovenskih 
Razumljivo, da je skušal Kogoj spričo takih nazorov in tako kritičnega presojanja sodobnih priredb kmalu kompozicijsko uveljaviti svoja načela. Koliko je storil v Gorici, ne vemo, tudi nam zapuščina ne nudi opore za domnevo, da se je s slovensko ljudsko pesmijo ukvarjal med študijem na Dunaju. Zagotovo pa je kmalu po prihodu v Ljubljano (1918. leta) nastal večji del zborovskih priredb, ki jih danes poznamo. ${ }^{32} \mathrm{~V}$ tem času je Kogoj izdal tudi priredbo Fleišmanove skladbe »Lahko nočc in tako potrdil misel, da so »njegove skladbe...v obliki, kakor jih je Fleišman priredil [,] neporabne, dobro uporabne pa $\mathrm{v}$ skrbni redakciji ${ }^{33}$ Jugoslovanska knjigarna pa mu je 1921. leta založila zbirko priredb »14 Marijinih pesmi (raznih slovenskih skladateljev) (. ${ }^{34}$ - Zlasti »Stoji, stoji mi polje« in prvi del suite »Trpeča srca« imata mnogo skupnih potez $\mathrm{s}$ temi priredbami: stavek je štiriglasna homofonija $\mathrm{z}$ vzorno samostojnimi glasovi, metrum melodične dikcije in ritmični zapis sta popolnoma usklajena, oblikovno gre za dvodelno pesem oz. nepravilno osemtaktno periodo, posebno barvo pa jim daje bogata in iznajdljiva harmonska govorica, polna zadržkov in septakordov, ki ustvarjajo, posebno v drugi, do takrat povsem neznano podobo izraznih razponov slovenske ljudske pesmi. Napeva sta iz Štrekljeve zbirke, kjer so natisnjeni Vrazovi zapisi. "Stoji, stoji mi polje ${ }^{35}$ je notirano ritmično pravilno, zato je Kogoj zamenjal samo pavze ob koncih stavkov z ustrezno podaljšanimi ritmičnimi vrednostmi njihovih sklepnih tonov in dosegel tako mirnejši, vsebini besedila primernejši potek melodije. Pesem sestavljata dve sedemtaktni periodi

narodnih pesmi« Marka Bajuka. Iz IV. = 1. zv. (Ljubljana, 1904) so izpisane pesmi št. 1-9, iz III. zv. (Ljubljana, 1908) št. 1-25, iz IV. zv. (Ljubljana, 1912) pa št. $1-9$.

32 »Stoji, stoji mi polje« je bila objavljena že 1921 leta, prav tako prvi stavek suite »Trpeča srca« (P I, notna priloga, str. 43), kar dovoljuje domnevo, da je takrat nastala cela suita. Obe deli poznamo samo $v$ prepisih. - Nedvomno poznejši pa je rkp. »Narodne«: to dokazuje pisava. Po kompozicijski gradnji in slogu sodeč je prireditev skoraj gotovo nastala v obdobju, ko se je Kogoj lotil opere »Kar hočete", torej med leti 1928-1932.

33 J (Jutro) V, št. 126, 28. V. 1924 — „Jurij Fleišman (1818-1874)《. Skladba je bila objavljena v P III, notna priloga, str. 25 kot Kogojeva »harmonizacija«. Rkp. je izgubljen.

${ }_{34}$ Kritika je zbirko lepo sprejela in potrdila bistvene poteze Kogojevih nazorov o prirejevanju. Franc Kimovec: "Nekatere pesmi so pravi biseri, Kogoj jih je pobral, osnažil, obrusil in jih vdelal v globoko - včasih skoro pregloboko - zamišljeno spremljanje, tako da so pesmi postale neverjetno plemenite in mehke. Zdaj lepota teh starih napevov šele kaže svojo popolno vrednoto...« (P I, št. 3-4, str. 7 - Marij Kogoj: 14 Marijinih pesmi«) — Stanko Premrl: »Povdarjam, da tako temeljito nam ni doslej še nobeden starejših pesmi priredil kot Kogoj. Pa tudi tako cerkvene, tako resnobne, vsako banalnost, trivialnost in vsakdanjost izključujoče so te od Kogoja prirejene Marijine pesmi, da služijo lahko za vzor ali vsaj za šolo nam vsem." (CG XLIV, str. 34 — Marij Kogoj: 14 Marijinih pesmi raznih skladateljev $\ll$ ).

35 Karel Štrekelj, Slovenske narodne pesmi, št. 1193, «V srcu se ljubezen melje« (z Murskega polja). Kogoj je le dvakrat bistveno spremenil besedilo: $v$ prvi vrstici I. kitice je zamenjal vrstni red besed (v orig.: »Stoji mi, stoji polje ), v drugi vrstici tretje pa je besedi »ljuba cartana« nadomestil z »draga miljena«. Ostale korekture so deloma pravopisne deloma slovnične, ker je pesem objavljena v dialektu. 
(obakrat $4+3$ takti) in priredba je $v$ drugi, tretji in četrti kitici obdržala to nesimetrično gradnjo, le v prvi kitici, ki jo pojo unisono moški glasovi, je začetno osminko spremenila $v$ četrtinko in podaljašala zadnji stavek $v$ osemtaktno periodo (polovinka s piko namesto sklepne četrtinke). Vtis elegičnega uvoda in podoba otožne pokrajine sta tako popolna. - Vse drugače zapletena je bila naloga ob pesmi »Mene moje srce boli«,$^{36}$ saj je Vrazov zapis napačen in nepregleden $;^{37}$ pravo melodijo, njen metrum in ritem je bilo treba torej šele poiskati:
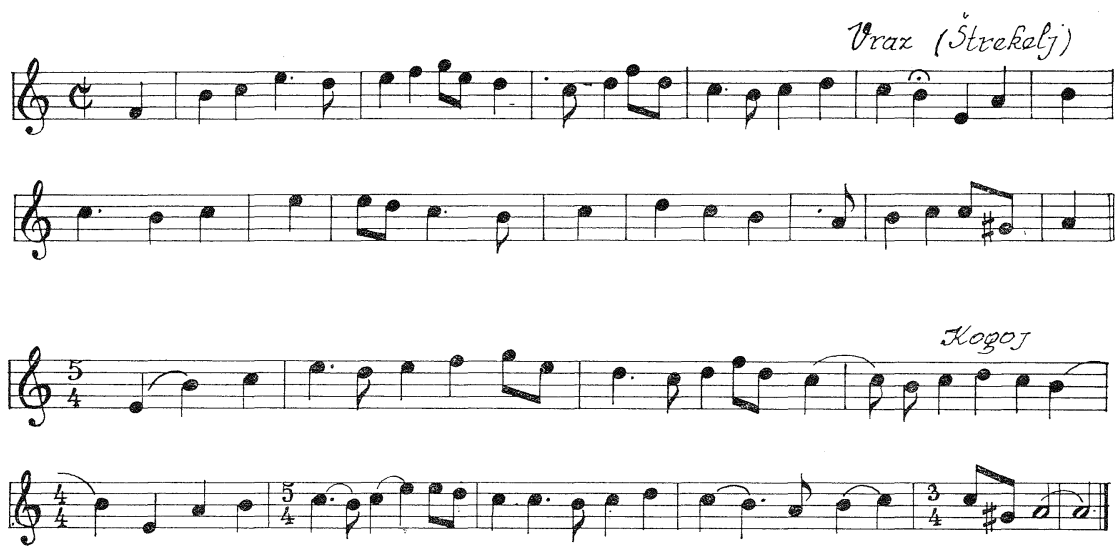

S tenkim občutkom za melodično dikcijo je Kogoj oživil arhaično lepoto tega $\mathrm{v}$ bistvu hipoeolskega napeva, vendar je presenetljivo, da ga je $\mathrm{v}$ suiti povezal z dvema izrazito durovskima, ritmično in melodično neprimerno manj izrazitima melodijama, ki estetsko ne segata tako globoko. Verjetno je hotel s »Trpečimi srcic pokazati predvsem, kako je treba združevati $\mathrm{v}$ venčke vsebinsko sorodne pesmi in ne »različne napeve brez vsake notranje motivacije.$^{38} \mathrm{Da}$ se je pri tem zavedal muzikalne neenotnosti prve in drugih dveh melodij, priča tudi kompozicijski prijem: namesto klasičnega štiriglasja uporablja zanje kontrapunktsko mnogo bolj razgiban in svobodnejši stavek, motivično delo, ležeči bas, komplementarne ritme, podvaja linije, opisuje (variira) napeve in išce zanimive modulacijske prehode. Posamezne kitice se iztekajo druga $v$ drugo ali pa jih povezujejo kratke medigre, kot pesmi, nekateri odlomki so včasih metrično spremenjeni in pri pesmi »Srce je žalostno « se drugi stavek periode $\mathrm{v}$ drugi kitici ponovi trikrat. Najzanimivešja pa je kljub temu spet harmonska gradnja. Osrednji del suite prehaja iz g-mola v B-dur (I. kitica), iz B-dura $v$ Des-dur (II. kitica), odtod $v$ f-mol in se končuje $v$ Des-duru

${ }^{36}$ Op.cit., št. 6325, »Mene srce boli po umrlih roditeljih« (od Cerovca). Objavljene so štiri kitice, Kogoj je uporabil samo prvo (?) z neznatnimi pravopisnimi izboljšavami.

37 Gl. o tem Beranič Davorin, Vrazovi zapisi narodnih melodij, C̆asopis za zgodovino in narodopisje VII, str. 232-270.

38 »O narodni pesmi«, str. 176. 
(III. kitica), sklepni del, )Zagorski zvonovi«, pa z enharmonično modulacijo poveže Des-dur z A-durom in tako vrne skladbo, ki se je pričela z arhaiziranim a-molom, $v$ njeno prvotno tonsko območje. Da bi bila logika tega razvoja kar najbolj očitna, zniža Kogoj v predzadnjem taktu cis v c in se $\mathrm{v}$ sklepnem akordu odreče terci. ${ }^{39}$ Vendar celota oblikovno ni uravnovešena: ena sama kitica brez ponovitev $\mathrm{v}$ prvem delu nasproti trem ( $\mathrm{s}$ ponovitvami drugega stavka periode) $\mathrm{v}$ drugem in dvema kiticama $\mathrm{v}$ tretjem delu razbija notranja sorazmerja suite in upravičuje misel, da gre za )majhno fantazijo na ... ljudske melodije.$^{40}{ }^{2}$ sekakor pa je skladatelj z njo daleč presegel tedanja slovenska prizadevanja in ustvaril našo prvo koncertno zborovsko partituro na ljudske teme.

Če so »Trpeča srca k kljub precejšnjim pevsko-tehničnim težavam vendarle predvsem intonančno zahtevna, pa je »Narodnac že izrazito virtuozno zborovsko delo in kaže - morda zavoljo sorodne zunanje slikovitosti, ki je Kogoja očitno mikala, nemara tudi zaradi časovne bližine nekaj značilnih potez )Vrabcev in strašila(c. Kompozicijsko so to formalne variacije, le da sta prvi kitici oblikovani enako in se skladateljeva variacijska fantazija razživi šele $\mathrm{v}$ naslednjih treh. Harmonski stavek ne prinaša novosti, spričo strožjih polifonih prepletov je celo za spoznanje preprostejši, presenečajo pa tenkočutne metrične in ritmične spremembe melodije ter klasicistični oblikovni načrt. Tema, osemtaktna perioda $\mathrm{s}$ ponovitvijo drugega stavka, je zaupana štiriglasnemu mešanemu zboru (sopran, alt I, alt II, bas) in obdelana kot dosleden kanon $\mathrm{v}$ primi med sopranom in prvim altom $\mathrm{z}$ ritmičnim premikom za eno četrtinko; drugi alt spremlja prvega $\mathrm{v}$ spodnji terci, izjemoma $\mathrm{z}$ ostalimi akordičnimi toni, bas pa je voden samostojno in samo na začetku ritmično imitira temo. Skupna značilnost vseh treh variacij je akordično opisovanje melodične linije $\mathrm{z}$ manjšimi notnimi vrednostmi in bogastvo metričnih odtenkov, zaradi katerih se nekajkrat spremeni tonovski način. Kljub temu Kogoj ohranja obliko osemtaktne periode, le da drugega stavka, razen v zadnji kitici, ne ponavlja več. ${ }^{41}$ Tej vzorni gradnji primeren je tudi tonalni načrt priredbe: G-dur (tema) - e-mol, G-dur (I. variacija) - c-mol, G-dur (II. variacija) — G-dur (III. variacija). Spričo opisanega kompozicijskega prijema in trdne oblikovalne logike, ki se odlično prilegata vsebini in obliki pesmi ter metaforiki besedila, je »Narodna« prav tako umetniško popolna interpretacija ljudskega napeva kot )Stoji, stoji mi polje爪. Njena slogovna izčiščenost $\mathrm{z}$ očitnimi neoklasicističnimi prvinami ter ustvarjalna domiselnost dokazujeta, da se je Kogoj v zadnjem obdobju svojega dela, po „Črnih maskah«, res pričel nagibati v novo stilno območje in tako dokončno prestopil meje dotedanjega sprireje-

39 Zelo značilni za njegov harmonski stavek so tudi detajli, ki nastajajo ob samostojnem vodenju glasov: izmikanja vodilnim taktom, alteracije, zadržki, kromatični prehodni toni, sept-in nonakordi.

40 Lipovšek Marijan, Marij Kogoj, Naša sodobnost IV, str. 775.

41 Tudi tu samo z znamenji za repeticijo. Seconda volta je stavek zaradi augmentacije sklepnih treh tonov razširjen $v$ pettaktje. 
vanja«, ne da bi pri tem zanemaril »zahteve, ki jih ima prireditelj do napevov ${ }^{42}{ }^{4}$

Da je imel pred seboj višje cilje in je videl naloge skladatelja ob glasbeni dediščini lastnega naroda tudi zunaj okvirov kompozicijsko nujno preprostega zborovskega interpretiranja ljudskih napevov, najbolje dokazujejo zgodnje klavirske variacije na pesem »Oj ta vojaški boben(. Misel nanje je spremljala Kogoja domala ves čas ustvarjanja. ${ }^{43}$ Skušal jo je dognati oblikovno in vsebinsko, vendar ohranjeni rokopisi pričajo, da je vedno znova odnehal zaradi neizdelanega načrta. Omahoval je med formalnimi in karakternimi variacijami: ob prvih ga je poleg ustvarjalnega temperamenta omejevala morda tudi struktura teme, ob drugih se je précej prepustil prostemu fantaziranju, ki mu je bila klasično postavljena tema domala nepotreben privesek. - Skoraj gotovo se je kateri poznejših osnutkov izgubil, zato ne moremo slediti razvoju zamisli od prvotne oblike klavirskih variacij z nekaterimi prvinami koncertantnega pianističnega prijema do particella, iz katerega bi bilo mogoče razbrati osnovne poteze instrumentacije za veliki orkester in nemara tudi stilno orientacijo v neoklasicizem, ki jo zasledimo v klavirskem izvlečku opere »Kar hočete爪. Kar je ohranjeno, seveda ne izpričuje tako stroge oblikovalne volje kot »Narodna in je kompozicijsko bližje suiti »Trpeča srca«, čeprav dovoljuje instrumentalni stavek Kogoju mnogo več svoboščin in širši fantazijski razmah. ${ }^{44} \mathrm{Za}$ odtenke njegove harmonske in pianistične invencije ter $\mathrm{v}$ dokaz, kako prosto je ravnal s folklornimi napevi, iščoč njihovo muzikalno bistvo zunaj ozkih meja tonike in dominante, so zelo značilni že prvi štirje takti teme. V G-duru:

$42 » O$ narodni pesmi«, l. c. - O novi stilni orientaciji gl. Loparnik B., Dramaturška in kompozicijska zasnova Kogojeve opere »Kar hočete«, str. 90-93.

43 Ohranjeni rkp. so, po pisavi sodeč, nastali v prvem obdobju njegovega dela v Ljubljani, verjetno med letoma 1918-1920, le ena skica je poznejša; o tem priča poleg pisave tudi papir z značilno razporeditvijo notnega črtovja: na enake liste si je Kogoj zapisal nekaj idej za opero »Kar hočete« (gl. mapo »Oj, ta vojaški boben« in prim. s skicami v mapi »Kar hočete«). Da pa se je ukvarjal z mislijo na variacije še med komponiranjem »Črnih mask«, priča njegov odgovor na vprašanja uredništva $J$ : »Blagovolili ste mi poslati par vprašanj glede mojega skladateljskega delovanja. Odgovarjam vam, da se momentano bavim s pripravo svoje opere na uprizoritev. Svojih načrtov ne nameravam naštevati, ker zadobijo pomen šele, ko jih uresničim. Tudi ne morem z gotovostjo povedati drugega, kakor da bom svojčas spisal koncertno simfonijo $\mathbf{v}$ treh stavkih [,] katere srednji del bodo tvorile variacije na narodno pesem ,Oj ta vojaški boben"« (J VII, št. 296, 24. XII. 1926 - Kaj se nam obeta v glasbi. Marij Kogoj.«) - O »pripravi opere na uprizoritev« gl. Klemenčič Ivan, Marij Kogoj - C̆rne maske (dipl. nal.), str. 22.

${ }^{44}$ Ohranjena sta dva rkp. v As-duru, prvi z dvema variacijama (Andante s poznejšim pripisom sostenuto), druga s eno (Andante), rkp. teme v G-duru (Andante sostenuto) ter deli notnih listov $\mathrm{z}$ odlomki ali skicami variacij $\mathbf{v}$ As-duru, Es-duru, E-duru in fis-molu. As-durov rkp. z dvema variacijama se pričenja kot čistopis in se po prvi variaciji nadaljuje s prvim zapisom ob klavirju, G-durov rkp. je očitno nastal v ustvarjalni naglici, le As-durov rkp. z eno variacijo je čistopis, čigar nadaljevanje (poznamo samo dva lista) se je izgubilo; identična s prejšnjim rkp. v As-duru je samo tema. Vse drugo ohranjeno gradivo dokazuje, da je mislil skladatelj začeto delo nadaljevati oz. izpopolniti na hitro skicirane domisleke. Poznejši rkp. je prvi zapis, skice na novo obdelane teme v As-duru. 

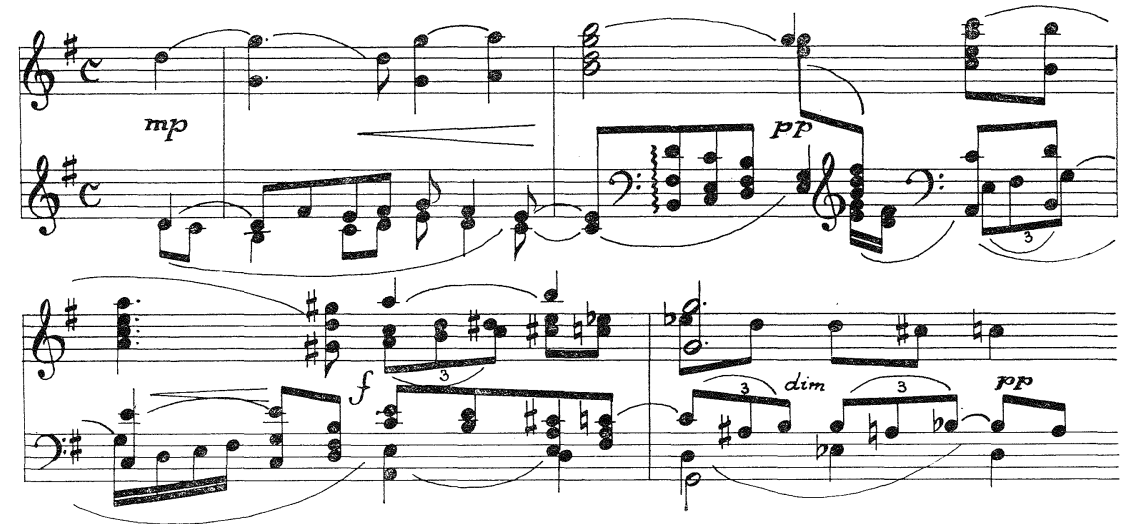

Prvotna oblika teme v As-duru:
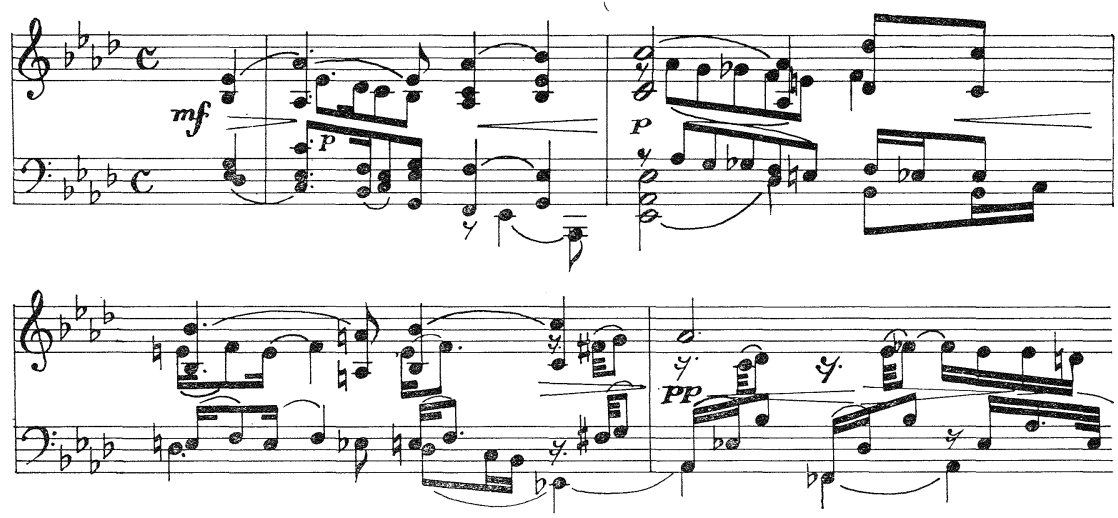

Edina izdelana formalna variacija $\mathrm{z}$ nespremenjeno temo: $:^{45}$
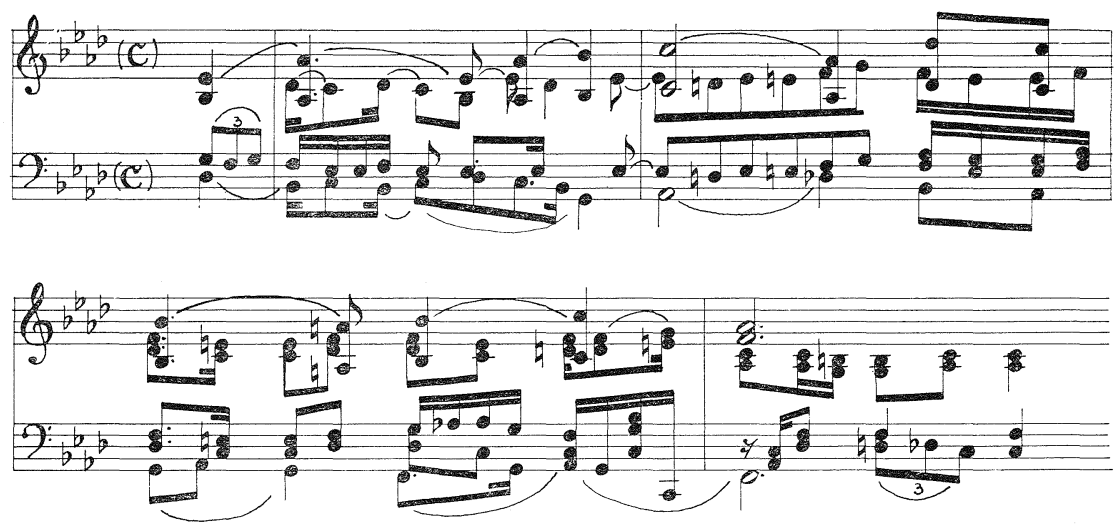

${ }^{45}$ Rkp. teme z dvema variacijama; druga je karakterna. 
Poznejša obdelava teme v As-duru:
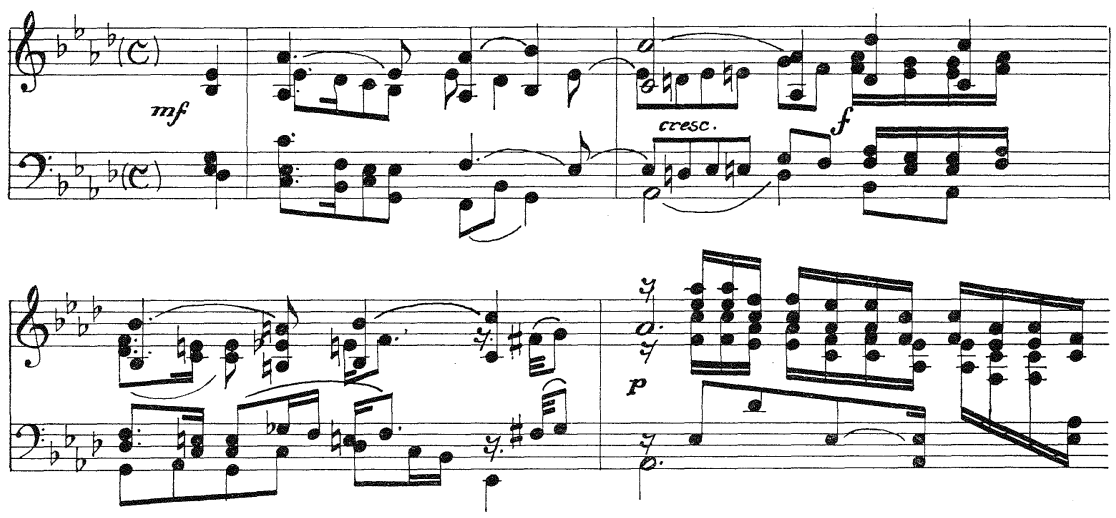

Oblikovno je »Oj ta vojaški boben« enodelna pesemska oblika (a $-a-b-a)$ in primerjava harmonske interpretacije vseh treh a stavkov $\mathrm{v}$ ohranjenih rokopisih bi pokazala še mnogo obsežnejši spekter Kogojeve iznajdljivosti. Njej nasproti je skladateljeva sposobnost spreminjanja melodične predloge $\mathrm{v}$ okviru formalne variacijske tehnike nenavadno skromna, zato ni naključje, da ohranja edina znana formalna variacija temo brez ornamentalnih dopolnitev ali celo metričnih novosti; povrhu je edina, ki se pričenja brez povezujoče medigre. Povsod drugod se melodična invencija razživi že $v$ teh vmesnih taktih in se potem docela sprosti $\mathrm{v}$ fantazijskem parafraziranju folklornega napeva. Za izraz in notranjo logiko Kogojeve glasbene misli, še zlasti pa za izrazito ekspresionistično sposobnost preoblikovanja dane teme sta obe ohranjeni variaciji najbolj zgovorno ponazorilo:
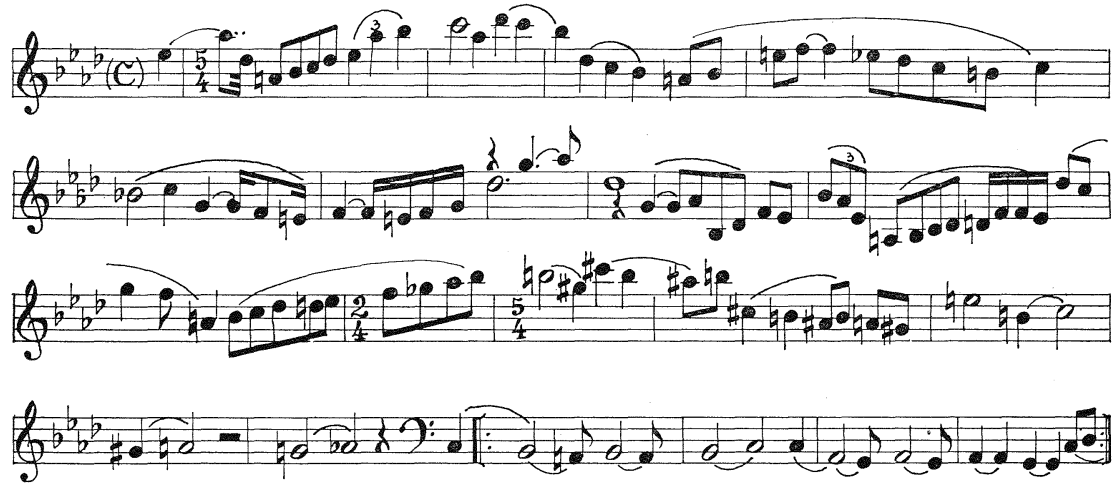


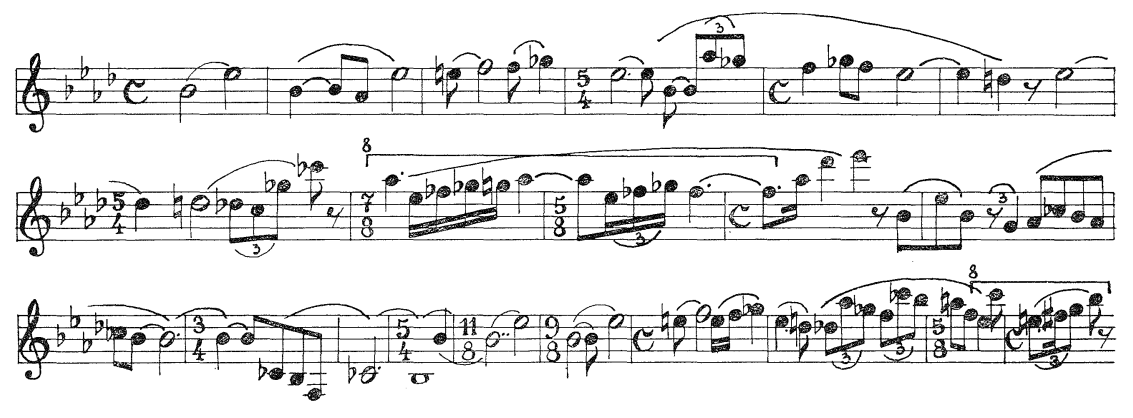

Ta popolnoma osebna, z vsebino pesmi nepovezana interpretacija melodije, ki postaja zgolj absolutno-muzikalna tematična osnova, zanika svoj izvor in potemtakem ne terja od skladatelja, da bi odkrival globlje vrednote folklornega bogastva mimo lastne ustvarjalne vizije, je Kogojev najzahtevnejši in najbolj samosvoj poseg $\mathrm{v}$ slovensko ljudsko glasbeno izročilo. $\mathrm{Z}$ njim je hotel dvigniti narodno pesem na sodobno kompozicijsko raven in $\mathrm{ji}$, pravzaprav zoper lastna načela, priznati enakopravno veljavo. Skromna zasnova izbrane pesmi ni vzdržala napetosti tolikšnega načrta, zato si ni znal izoblikovati trdnega koncepta in zamisli ni zmogel uresničiti. Kljub temu so nedokončane variacije na temo » $\mathrm{Oj}$ ta vojaški boben « pomembno dejanje $\mathrm{v}$ zgodovini slovenske moderne glasbe: prvi umetniško polnokrvni poskus, uveljaviti narodno pesem $\mathrm{v}$ obsežni koncertantni pianistični obliki.

Kako bi ravnal Kogoj s folklornim blagom v orkestralni partituri, ni mogoče dognati - epizoda $v$ »Črnih maskah « pove premalo. ${ }^{46}$ Popolnejši odgovor bi nam dala opera »Kar hočete (, $v$ katero je »vpletel tudi narodno pesem (c. ${ }^{47}$ Ohranjeni klavirski izvleček nepopolnega I. in II. dejanja in skice, ki jih poznamo, dokazujejo, da je mislil na precej znanih ljudskih napevov, žal pa - z redkimi izjemami - ne vemo, kako bi jih bil dokončno uporabil. Tudi tokrat ga ni zanimala provenienca melodij, izbiral jih je $v$ skladu $\mathrm{z}$ razpoloženji na odru in seveda tiste, za katere je sodil, da so pristno slovenske, očitno pa je hotel preizkusiti vse možne kompozicijske prijeme: priredbo, obdelavo, variacije, parafrazo in fantazijo s svobodno uporabo motivičnega materiala. Stilno so ti načrti ali končani odlomki blizu »Narodnic in kažejo novo, v neoklasicizem usmerjeno orientacijo. Iz njih je mogoče razbrati najbolj celovito podobo skladateljevih nazorov in praktičnega ravnanja z narodno pesmijo. Napev »Rasti, rasti rožmarinđ, s katerim je želel slikati otožna, zamišljena razpoloženja, je uporabil sedemkrat. Kot skromen quodlibet zveni bitonalna povezava z melodijo »Čuk se je oženil«:

46 V prvi sliki I. dejanja je uporabljenih nekaj odlomkov slovenskih narodnih pesmi, predvsem »Škrjanček poje, žvrgoli« in »Rasti mi, rasti, travca zelena«. Gl. o tem Klemenčič I., op. cit., str. 68-69.

47 SN LXI, št. 137, 16. VI. 1928 - „Kaj ustvarjajo in snujejo naši umetniki. Nadaljevanje zanimive ankete o delovanju pionirjev slovenske kulture. Marij Kogoj.« Gl. o tem še Loparnik B., op. cit., str. 92-93. 


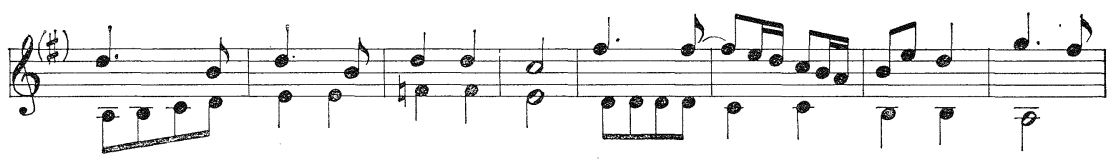

Doslednejši, a ritmično manj zvest je citat, edini, ki uporablja celotno periodo; proti koncu napev vse bolj opisuje, nato preide $\mathrm{v}$ fantazijsko nadaljevanje:

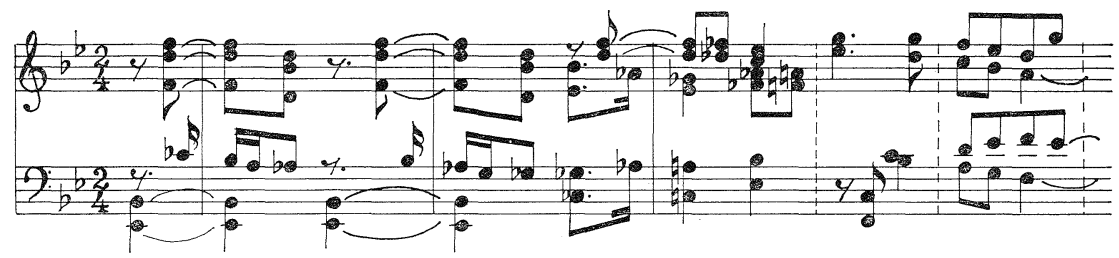

Metrično zanimiva je skica, ki druži jamb in trohej v nedosledni augmentirani kanon:

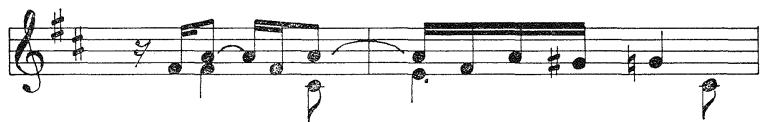

$\mathrm{V}$ ohranjenih osnutkih najdemo tudi začetek dvojnega kanona $\mathrm{v}$ seksti:

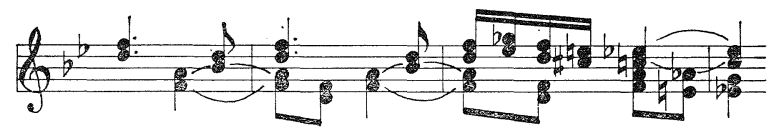

Kogoj ga je, nekoliko predrugačenega, uporabil $\mathrm{v}$ tretji sliki II. dejanja. Zaporedje glasov je ostalo isto, spremenil pa je tonovski način, intervalni razmik (kvarta namesto sekste) ter ritmični odnos proposte in risposte; to je zamenjalo njun tonalni odnos:

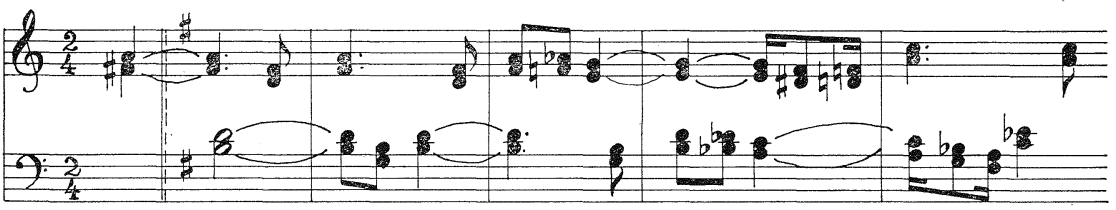

Nič manj pa ni značilna uporaba posameznih motivov pesmi $\mathrm{v}$ tej sliki: cela vrsta novih kontrapunktičnih zvez, metričnih sprememb, kanoničnih odlomkov in novosti $v$ duktusu dokazuje živo ustvarjalno fantazijo. Napev je variiran le še dvakrat. Prvič $v$ instrumentalnem uvodu $\mathrm{z}$ nakazanim diminuiranim kontrapunktom zgornjega glasu, prostimi prehodi in zamenjanima stavkoma periode:

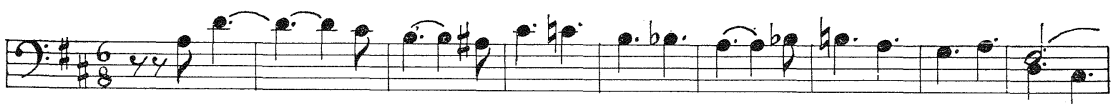


drugič $\mathrm{v}$ čistem kvartetnem vodenju glasov, mirno in poetično:

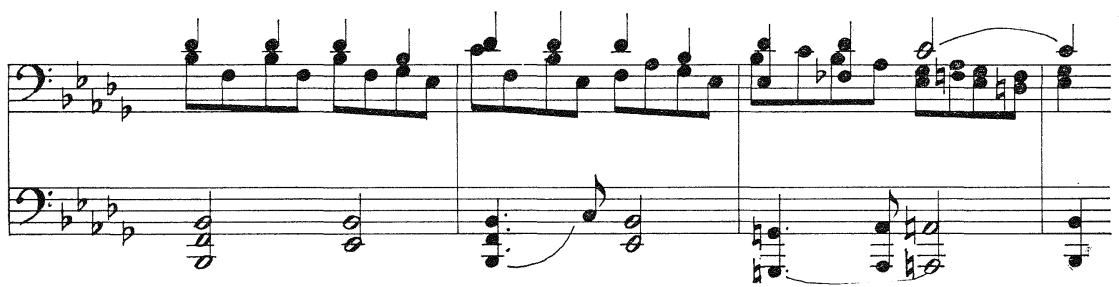

Korenine Kogojevega zanimanja za slovensko ljudsko pesem moramo iskati $v$ njegovi mladosti. Živel je sredi nacionalno ogroženega prostora in dojemal folkloro kot dokaz etnične samobitnosti, zato ga je tudi pozneje zanimal samo tisti del folklorne dediščine, ki mu je priznaval pristnost in muzikalno osamosvojenost. Njegovi pogledi na domače narodno blago so rojeni iz tenkočutne umetniške intuicije in zdravo kritični ob slehernem zlorabljanju ljudske melodike. Kot ekspresionist, ki s svojo muziko razkriva bistvene vzgibe človekove notranjosti, je prvi pokazal vsebinske razsežnosti slovenske narodne pesmi in ji dal primerno kompozicijsko veljavo, $\mathrm{s}$ tem pa pričel novo obdobje $\mathrm{v}$ zgodovini našega glasbenega življenja. Prepričan, da »naj [vsakdo] komponira, kakor misli, da je pravc ${ }^{48}$ ni iskal nacionalnega bistva umetniškega izpovedovanja $\mathrm{v}$ posnemanju ali celo citiranju folklorne melodike, temveč $v$ resničnosti skladateljeve izpovedi, ki edina lahko dokaže njegove etnične korenine. Tako je $\mathrm{z}$ nazori o slovenski ljudski pesmi daleč presegel svoje sodobnike in pokazal pravo bistvo problema, ki ga je njegovo okolje tisti čas razumelo še v okviru romantičnih idej. Da se je v iskanju novih slogovnih območij naslonil tudi na narodno pesem, torej ni naključje.

\section{SUMMARY}

Marij Kogoj, the most famous Slovene expressionist composer, occupied himself throughout his life, although he had his own well defined outlook in music, with the problem of Slovene folk-songs. Considered from a scientific point of view, his ideas are an incomplete and undocumented collection of general elucidations and his own assumptions, yet they are interesting and valuable because they contain statements arising from intuition, later confirmed by ethnomusicological research. Kogoj's main achievement in his occupation with folk-lore was the raising of the Slovene folk-song to the full artistic standard of the concert hall. As a composer he himself was not generally very active in this field and his two main projects: piano variations on the song »Oh, this Military Drum!« and the opera "As You Like It in which he abundantly used folk-song material, remained unfinished. Nevertheless, his choral arrangements of folk-songs such as: "There Lies, There Lies a Field«, his suite »Suffering Hearts«, and »A Folk-Song« are a suf-

${ }^{48}$ J V, št. 98, 24. IV. 1924 — »Marij Kogoj: Vzajemnost evropskih kultur «: "Ali naj bo narodna pesem izhodišče za našo muziko ali le človek, to mora vsak ustvarjajoči zase določiti sam.« 
ficient proof of how far, in his artistic views on folk-lore and particularly in his own compositions, he rose above the Slovene milieu of that time which still conceived the essence of the problem in terms of Romanticism. Kogoj discovered by means of his inventive solutions (arrangement, variation, paraphrase, fantasy with a free employment of motifs) and particularly by his rich harmonic idiom and his lovely contrapunctal treatment new content dimensions of the Slovene folk-song and so he proved its parity with other folk-lore material. In his compositions of this kind the stylistic development from expressionism to neoclassicism can be very clearly perceived. 